\title{
Analisis Dampak Disiplin Kerja Terhadap Motivasi Pegawai (Study Kasus Di Bpsdm Provinsi Jambi)
}

\author{
Suwarto \\ Widyaiswara BPSDM Prov. Jambi \\ Correspondence email: suwartoireng @gmail.com
}

\begin{abstract}
The purpose of this study is to find out: (1) an overview of work discipline, and employee motivation at the Jambi Province Human Resources Development Agency. (2) To determine the effect of work discipline on employee motivation at the Jambi Province Human Resources Development Agency. This research is descriptive and verification. The population in this study are employees of the Jambi Province Human Resources Development Agency. The research sampling technique used Stratified Sampling technique. The total sample in this study was 50 respondents. Data were analyzed using 2 (two) ways, namely using descriptive analysis using a Likert scale. Descriptive research results indicate, the average level of respondents' answers to the variable work discipline $(X)$ of 3,188. The average level of respondents' answers to the motivation variable $(Y)$ was 3.113 .
\end{abstract}

Keywords: work discipline, motivation, BPSDM

\section{PENDAHULUAN}

Pegawai Negeri Sipil (PNS) mempunyai peranan yang sangat krusial dalam menentukan keberhasilan penyelenggaraan pemerintahan dalam jalannya pembangunan suatu daerah melalui instansi tempat mereka bekerja. Dimana, sosok PNS disini adalah sosok individu yang memiliki kompetensi sebagai pelayan masyarakat. Selain dari tuntutan yang mengharuskan bahwa setiap PNS tersebut juga memiliki sejumlah perilaku dalam bekerja yang optimal, yaitu disiplin, ulet, kerja keras, konsekuen, konsisten, bertanggungjawab, kreatif, inovatif, pro-aktif, dan mandiri. Dalam pelaksanaan pekerjaan sendiri, para pegawai tentu memiliki kesulitan dan permasalahan yang timbul. Disinilah dituntut adanya pengetahuan dan kemampuan yang sesuai dengan bidang pekerjaan yang dilaksanakan. Sebab, apabila pekerjaan dilakukan dengan tidak berdasarkan kemampuan maupun pengetahuan, serta pengalaman yang memadai maka hasil kerja yang diinginkan tidak akan tercapai. Untuk itulah, dalam pengukuran kinerja pegawai, suatu instansi pemerintahan seperti Badan Pengembaga Sumberdaya Manusia Provinsi Jambi (BPSDM) harus memperhatikan para pegawainya dalam melaksanakan aktivitas kerja sehari-hari.

Selain itu, pihak pimpinan sendiri harus memperhatikan disiplin dalam bekerja dari masing-masing pegawai pada Pengembaga Sumber Daya Manusia Provinsi Jambi (BPSDM). Tanpa adanya kedisiplinan kerja, pekerjaan yang diberikan tidak akan selesai tepat pada waktunya dan dapat menurunkan tingkat pelayanan kepada masyarakat yang berhubungan langsung dengan organisasi maupun instansi pemerintahan tersebut. Sastrohadiwiryo (2002:291), mengemukakan bahwa disiplin kerja dapat diartikan sebagai suatu sikap menghormati, menghargai, patuh dan taat terhadap peraturan uang berlaku, baik yang tertulis maupun yang tidak tertulis serta sanggup menjalankannya dan tidak mengelak untuk menerima sanksi-sanksinya apabila ia melanggar tugas dan wewenang yang diberikan kepadanya. Dengan demikian, dengan adanya disiplin yang ditegakkan kepada setiap pegawai dalam pelaksanaan aktivitas kerja mereka sehari-hari, maka para pegawai akan terbiasa untuk mempertanggungjawabkan pekerjaan yang diberikan kepada mereka. Sementara, apabila para pegawai lalai atau sengaja tidak mentaati segala peraturan dalam instansi, mereka akan menerima hukuman maupun sanksi yang diberikan dengan sikap terbuka.

Adapun tingkat kedisiplinan pegawai pertama-tama dan pada umumnya dapat dilihat dari absensi pegawai dalam bekerja. Hal ini dikarenakan, apabila para pegawai menghargai waktu kerja dengan sebaik mungkin, maka para pegawai akan terbiasa melaksanakan pekerjaan yang diberikan sesuai dengan waktu yang telah ditentukan, tanpa harus mengulur-ulur waktu, dan tentu sangat disayangkan apabila hal tersebut tidak dapat segera diantisipasi. Hal ini dikarenakan, lambat laun akan berdampak pada motivasi kerja para pegawai dalam kegiatan sehari-hari. Motivasi kerja sendiri disini berperan sebagai pendorong dan sebuah energi bagi para pegawai untuk dapat melaksanakan tanggung jawab yang diberikan kepada mereka dengan sebaik mungkin. Oleh karena itu, disiplin kerja dan motivasi kerja masih memiliki suatu hubungan atau keterikatan satu sama lain sebagai faktor intern dalam diri seseorang pada umumnya, dan pada para pegawai pada khususnya. Siagian (2005:74), mengemukakan bahwa motivasi adalah daya pendorong yang mengakibatkan seseorang anggota organisasi mau dan rela untuk mengerahkan kemampuan baik dalam bentuk keahlian, keterampilan, tenaga dan waktunya untuk menyelenggarakan berbagai kegiatan yang menjadi tanggung jawabnya, dan menunaikan kewajibannya dalam rangka pencapaian tujuan dan berbagai sasaran organisasi yang telah ditentukan sebelumnya. 
Dengan demikian, dapat dikatakan bahwa motivasi dalam bekerja sangat diperlukan bagi masing-masing pegawai untuk selalu bertanggungjawab dalam pelaksanaan aktivitas kerja sehari-hari, maupun pada akhirnya akan membantu dalam meningkatkan kinerja pegawai itu sendiri. Dengan adanya motivasi, seseorang akan merasa terbiasa dalam menyelesaikan pekerjaan secara tepat waktu, efisien dan efektif dalam mengerjakan tugas yang diberikan, maupun teliti terhadap hasil kerja yang telah dilakukan. Penelitian berkaitan dengan elemen-elemen organisasi seperti disiplin kerja dan motivasi telah banyak dilakukan oleh peneliti, dalam rangka pencapaian tujuan organisasi seperti yang tercantum dalam visi dan misi Pengembaga Sumberdaya Manusia Provinsi Jambi (BPSDM), elemen-elemen tersebut tidaklah berdiri sendiri, melainkan secara bersama-sama ikut memberikan konstribusi pada pencapaian keunggulan kompetitif yang akan membantu pada pencapaian tujuan utama organisasi berupa kinerja yang tinggi. Oleh sebab itu penelitian yang telah dilakukan ini untuk mengetahui, pengaruh disiplin kerja terhadap motivasi pegawai pada Badan Pengembagan Sumber Daya Manusia Provinsi Jambi (BPSDM).

\section{Literatur Review}

Disiplin Kerja

Disiplin pada dasarnya atau lebih lazimnya berasal kata "discipline", artinya yang menunjukkan suatu ide hukuman. Meskipun demikian, bukan artinya (arti disiplin) yang sebenarnya. Lebih jauh, disiplin sendiri berasal dari kata latin, yakni "disciplina", yang berarti latihan atau pendidikan kesopanan dan kerohanian, serta pengembangan tabiat. Dengan kata lain, disiplin kerja dalam hal ini lebih menekankan pada bantuan kepada para pegawai untuk mengembangkan sikap yang layak terhadap pekerjaannya, dan merupakan cara pengawas dalam membuat peranannya dalam hubungannya dengan disiplin. Fathoni (2006:130), mengemukakan bahwa dalam dunia kerja, disiplin kerja pada para pegawai dapat diartikan sebagai sikap pegawai yang mematuhi semua peraturan dan ketentuan yang berlaku dalam suatu organisasi, seperti datang dan pulang tepat waktu, mengerjakan semua pekerjaan dengan baik, maupun tidak mangkir dari tugas yang diberikan. Hasibuan (2002:193), menyatakan bahwa disiplin kerja adalah kesadaran dan kesediaan seseorang mentaati semua peraturan dan norma-norma sosial yang berlaku. Kesadaran adalah sikap seseorang yang secara sukarela mentaati semua peraturan dan sadar akan tugas dan tanggung jawabnya, kesediaan adalah suatu sikap, tingkah laku, dan peraturan perusahaan, baik yang tertulis maupun tidak.

Sastrohadiwiryo (2002:291), mengemukakan bahwa disiplin kerja dapat diartikan sebagai suatu sikap menghormati, menghargai, patuh dan taat terhadap peraturan uang berlaku, baik yang tertulis maupun yang tidak tertulis serta sanggup menjalankannya dan tidak mengelak untuk menerima sanksi-sanksinya apabila ia melanggar tugas dan wewenang yang diberikan kepadanya. Sulistiyani dan Rosidah (2003:236), dalam memberikan penilaian terhadap disiplin kerja para pegawai, hendaknya mengikuti beberapa prinsip-prinsip atau dasar-dasar, antara lain sebagai berikut : Keadilan dan layanan sama rata: Pertimbangan minat dan keperluan kerja:Kebebasan tunduk pada peraturan: Menghormati sesama individu: Hubungan sesama manusia untuk suasana kerja yang harmonis: Harmonisasi pegawai dan pimpinan.

Dengan demikian, dapat disimpulkan bahwa disiplin kerja adalah bentuk pengendalian diri pegawai dan pelaksanaan yang teratur, serta menunjukkan tingkat kesungguhan tim kerja dalam suatu organisasi. Selain itu, kecakapan disiplin ditunjukkan dengan tidak mempertimbangkan apakah aturan yang ditaati bermanfaat atau tidak. Hal ini pada akhirnya membuat suatu penekanan terhadap disiplin kerja yang dapat membuat pegawai mampu bergairah untuk bekerja, atau malah sebaliknya. Adapun faktor-faktor yang dapat mempengaruhi disiplin kerja menurut Sastrohadiwiryo (2002:301) dapat dibedakan menjadi beberapa hal, antara lain sebagai berikut : adanya peraturan atau tata tertib perusahaan, adanya tindakan korektif atau hukuman bagi pelanggaran tata tertib, adanya rasa tanggung jawab seseorang terhadap tugas-tugas yang diberikan kepadanya, harus adanya tujuan dan kemampuan, tujuan ini harus dinyatakan dengan jelas dan ditetapkan secara ideal dan cukup menantang bagi kemampuan karyawan. Pekerjaan yang dibebankan harus disesuaikan dengan kemampuan karyawan yang bersangkutan, harus adanya teladan pimpinan, sangat berperan dalam menetukan kedisiplinan karyawan, karena pemimpin dijadikan teladan dan panutan oleh bawahannya; harus adanya balas jasa, hal ini ikut mempengaruhi kedisiplinan karyawan, karena balas jasa akan memberikan kepuasan dan kecintaan karyawan terhadap pekerjaannya, harus adil, karena dengan keadilan akan mendorong terwujudnya kedisiplinan karyawan hal ini disebabkan ego dan sifat manusia yang selalu merasa dirinya penting dan minta diperlakukan sama dengan manusia lainnya, waskat (pengawasan melekat), yaitu suatu tindakan nyata dan efektif untuk mencegah atau mengetahui kesalahan, membetulkan kesalahan, memelihara kedisiplinan, menjadi sistem-sistem kerja yang paling efektif dan menciptakan sistem internal kontrol yang terbaik dalam pencapaian tujuan perusahaan, ketegasan, dalam menegur dan menghukum setiap karyawan yang indisipliner akan mewujudkan kedisiplinan yang baik pada perusahaan tersebut, dan ubungan terhadap manusia, yaitu hubungan yang harmonis ikut mencipakan kedisiplinan yang baik pada suatu perusahaan.

Selanjutnya Hasibuan (2002:195), mengemukakan bahwa ada beberapa indikator yang dapat dijadikan sebagai tolok ukur dalam melihat sejauhmana tingkat kedisiplinan seorang pegawai dalam suatu organisasi, antara lain sebagai berikut :1) Tujuan dan Kemampuan. Tujuan dan kemampuan ikut mempengaruhi tingkat kedisiplinan karyawan. 
Tujuan yang akan dicapai harus jelas dan ditetapkan secara ideal serta cukup menantang bagi kemampuan karyawan. Hal ini berarti bahwa tujuan (pekerjaan) yang dibebankan kepada karyawan harus sesuai dengan kemampuan karyawaan bersangkutan, agar dia bekerja sungguh-sungguh dan disiplin dalam mengerjakannya:2) Kepemimpinan. Kepemimpinan sangat berperan dalam menentukan kedisiplinan karyawan. Karena pimpinan dijadikan teladan dan panutan oleh para bawahannya. Pimpinan jangan mengharapkan kedisiplinan bawahannya baik jika dia sendiri kurang disiplin:3) Balas Jasa. Balas jasa (gaji dan kesejahteraan) ikut mempengaruhi kedisiplinan karyawan karena balas jasa akan memberikan kepuasan dan kecintaan karyawan terhadap perusahaan / pekerjaannya. Jika kecintaan karyawan semakin baik terhadap pekerjaan, kedisiplinan mereka akan semakin baik pula:4) Keadilan. Keadilan ikut mendorong terwujudnya kedisiplinan karyawan, karena ego dan sifat manusia yang selalu merasa dirinya penting dan minta diperlakukan sama dengan manusia lainnya. Dengan keadilan yang baik akan menciptakan kedisiplinan yang baik pula. Jadi, keadilan harus diterapkan dengan baik pada setiap perusahaan supaya kedisiplinan karyawan perusahaan baik pula: 5) Waskat. Waskat (pengawasan melekat) adalah tindakan nyata dan paling efektif dalam mewujudkan kedisiplinan karyawan perusahaan. Waskat efektif merangsang kedisiplinan dan moral kerja karyawan. Karyawan merasa mendapat perhatian, bimbingan, petunjuk, pengarahan, dan pengawasan dari atasannya: 6) Ketegasan. Ketegasan pimpinan dalam melakukan tindakan akan mempengaruhi kedisiplinan karyawan.. Pimpinan harus berani dan tegas, bertindak untuk menghukum setiap karyawan yang indisipliner sesuai dengan sanksi hukuman yang telah ditetapkan:7) Sanksi. Sanksi berperan penting dalam memelihara kedisiplinan karyawan. Dengan sanksi hukuman yang semakin berat, karyawan akan semakin takut melanggar peraturan-peraturan perusahaan, sikap, perilaku indisipliner karyawan akan berkurang.

Dengan demikian, setiap individu harus mendapat kesempatan yang adil/netral, serta memohon bantuan atas tindakan disipliner yang dilakukannya. Hal ini merupakan hak seorang pegawai, termasuk juga hak untuk diberitahu mengenai alasan-alasan tindakan disiplin, dan untuk membantah alasan-alasan tersebut dengan mengajukan keterangan lain, serta memperoleh jawaban dengan pertimbangan yang jujur, serta peninjauan kembali sebelum dibuat keputusan terakhir.

\section{Motivasi}

Motivasi bersal dari kata latin, yakni "Movere", yang artinya dorongan atau menggerakkan. Motivasi (motivation) dalam manajemen hanya ditujukan pada sumber daya manusia umumnya dan bawahan pada khususnya. Motivasi mempersoalkan bagaimana caranya mengarahkan daya dan potensi bawahan, agar mau bekerja sama secara produktif berhasil mencapai dan mewujud tujuan yang telah ditentukan. Harsey, et, all (2002:27), mengemukakan bahwa motives are sometimes defined as needs, wants, drives, or impulses within the individual. Motives are directed toward goals, which may be conscious or subconcious. Artinya, motivasi dapat digambarkan sebagai dorongan, kebutuhan, kekurangan, yang mengarahkan atau mendorong individu ke arah tujuan, baik dilakukan secara sadar atau tidak.

Hasibuan (2000:142), mengemukakan bahwa motivasi adalah pemberian daya penggerak yang menciptakan kegairahan kerja dalam diri seseorang agar mau bekerja sama, bekerja secara efektif dan terintegrasi dengan segala daya upaya dan kemampuannya untuk mencapai kepuasan. Siagian (2005:74), mengemukakan bahwa motivasi adalah daya pendorong yang mengakibatkan seseorang anggota organisasi mau dan rela untuk mengerahkan kemampuan baik dalam bentuk keahlian, keterampilan, tenaga dan waktunya untuk menyelenggarakan berbagai kegiatan yang menjadi tanggung jawabnya, dan menunaikan kewajibannya dalam rangka pencapaian tujuan dan berbagai sasaran organisasi yang telah ditentukan sebelumnya.

Dengan demikian, dapat disimpulkan bahwa motivasi pada diri pegawai merupakan suatu keadaan psikis yang ada dalam diri seseorang yang mendorong mereka untuk berperilaku. Dimana, keadaan psikis tersebut mencakup kemauan berprestasi dengan baik, semangat dan gairah kerja, kemauan menjalankan perintah, dan kemauan bekerja sama dalam organisasi dimana mereka bekerja saat ini. Hasibuan (2000:141), mengemukakan bahwa ada beberapa tolok ukur dalam menilai motivasi kerja dari seorang pegawai, antara lain sebagai berikut : Keinginan Untuk Hidup (The Desire to Live); Keinginan untuk hidup merupakan keinginan utama dari setiap orang, manusia bekerja untuk dapat makan, dan untuk dapat melanjutkan hidup; Keinginan Untuk Suatu Posisi (The Desire for Position); Keinginan untuk suatu posisi dengan memiliki sesuatu yang merupakan keinginan manusia yang kedua, dan ini salah satu sebab mengapa manusia mau bekerja; Keinginan Akan Kekuasaan (The Desire for Power); Keinginan akan kekuasaan merupakan keinginan selangkah di atas keinginan untuk memiliki yang mendorong orang mau bekerja; Keinginan Akan Pengakuan (The Desire for Recognation). Keinginan akan pengakuan, penghormatan, dan status sosial, merupakan jenis terakhir dari kebutuhan yang mendorong orang untuk bekerja. Dengan demikian, setiap pekerja mempunyai motif keinginan (want) dan kebutuhan (needs) tertentu, serta mengharapkan kepuasaan dari hasil kerjanya.

Ranupandojo, dkk (2000:145), mengemukakan bahwa ada beberapa indikator yang dapat dijadikan sebagai penilaian terhadap motivasi pegawai, antara lain sebagai berikut: Achievement motivation, yaitu suatu keinginan untuk 
mengatasi/mengalahkan suatu tantangan, untuk kemajuan dan pertumbuhan; Affiliation motivation, yaitu dorongan untuk melakukan hubungan dengan orang lain; Competence motivation, yaitu dorongan untuk melakukan pekerjaan yang bermutu; Power motivation, yaitu dorongan yang dapat mengendalikan suatu keadaan. Dalam hal ini ada kecenderungan untuk mengambil resiko dan menghancurkan rintangan yang ada. Yuda (2012:7), mengemukakan bahwa terdapat beberapa indikator atau tolok ukur yang dapat digunakan untuk memberikan penilaian terhadap motivasi para pegawai dalam melaksanakan aktivitas kerja mereka pada sebuah organisasi maupun instansi, antara lain sebagai berikut : Prestasi kerja yang tinggi, gaji yang tinggi, mempunyai dedikasi yang tinggi, menyenangi profesinya, bekerja karena panggilan hati nurani, mendapatkan penghargaan dari pimpinan.

Apabila suatu instasi mampu meningkatkan motivasi kerja pegawainya maka mereka akan memperoleh banyak keuntungan diantaranya pekerjaan akan lebih cepat diselesaikan, kerusakan akan dapat dikurangi, absen akan dapat diperkecil, kemungkinan perpindahan bukan saja kinerja pegawai dapat ditingkatkan, tetapi juga biaya yang timbul sebagai akibat dari turunya semagat dan kegairahan kerja dapat diperkecil. Yuda (2012:10), mengemukakan bahwa dalam melihat bagaimana motivasi kerja yang ada pada seorang pegawai dapat dibedakan menjadi beberapa faktor yang mempengaruhinya, antara lain sebagai berikut : Kebutuhan fisiologis, merupakan kebutuhan yang sangat diperlukan dalam menunjang kelancarana aktivitas yang dilaksanakan; Kebutuhan rasa aman, merupakan ketenangan yang diperoleh ketika melakukan aktivitas dan tidak merasa terganggu oleh berbagai gangguan; Kebutuhan social, merupakan kebebasan dalam berinteraksi dengan orang lain, tanpa adanya rasa paksaan maupun kecurigaan; Kebutuhan penghargaan, merupakan rasa diakuinya suatu pekerjaan yang telah dilaksanakan, tentuya pekerjaan tersebut berhasil secara maksimal dan optimal; Kebutuhan merealisasikan diri, merupakan kebutuhan dalam meningkatkan kemampuan diri, serta mengaktualisasikan diri dalam pekerjaan.

Sementara, Hasibuan (2000:101), mengemukakan bahwa sebenarnya motivasi memiliki tujuan-tujuan yang ingin dicapai, sehingga pemimpin suatu organisasi harus memperhatikan beberapa faktor, antara lain sebagai berikut : Meningkatkan moral dan kepuasan kerja pegawai; Meningkatkan produktivitas kerja pegawai; Mempertahankan kestabilan pegawai perusahaan; Meningkatkan kedisiplinan pegawai; Mengefektifkan pengadaan pegawai; Menciptakan suasana dan hubungan kerja yang baik; Meningkatkan loyalitas, kreativitas, dan partisipasi pegawai; Meningkatkan kesejahteraan pegawai; Mempertinggi rasa tanggung jawab pegawai terhadap tugas-tugasnya; Meningkatkan efisiensi penggunaan alat-alat dan bahan baku.

Variabel disiplin kerja dan motivasi kerja sudah banyak di teliti oleh peneliti terdahulu. Lutfi dkk (2018) dalam penelitiannya menyimpulkan bahwa disiplin kerja dan gaya kepemimpinan berpengaruh terhadap kinerja melalui motivasi secara simultan dan parsial. Selanjutnya penelitian yang dilakukan oleh Eva Lestari dan Kasmir (2016) menemukan bahwa disiplin memiliki pengaruh positif dan signifikan terhadap kinerja, dan Motivasi berpengaruh positif dan signifikan terhadap kinerja. Demikian juga penelitian yang dilakukan oleh Oktaviannur dan Pratama (2016) motivasi kerja berpengaruh positif terhadap kinerja karyawan dan disiplin kerja berpengaruh positif terhadap kinerja karyawan.

\section{METODE}

Populasi penelitian ini adalah semua pegawai BPSDM yang berjumlah 105 orang. Sedangkan unit analisis adalah individu, yaitu pegawai staff fungsional umum berstatus Pegawai Negeri Sipil (PNS). Teknik pengambilan sampel penelitian menggunakan teknik Stratified Sampling. Total sampel dalam penelitian ini adalah 50 responden. Data di analisis dengan menggunakan 2 (dua) cara, yaitu Menggunakan analisis deskriptif dengan menggunakan skala likert. Sehubungan dengan struktur pengaruh antar variabel, ada dua jenis variabel penelitian yang diteliti, yaitu: disiplin pegawai (X)sebagai variabel bebas (indenpendent) dan motivasi kerja (Y) variabel terikat (dependent). Metode penelitian yang digunakan dalam penelitian ini adalah penelitian kuantitatif, dengan menggunakan pendekatan deskriftip kuantitatif dan verifikatif. Alat analisis yang digunakan dalam penelitian ini adalah analisis Regresi. Secara umum kerangka pemikiran meliputi variabel disiplin kerja dan variabel motivasi kerja.

Variabel yang dianalisa sebagai variabel indenpenden (variabel bebas) yaitu Disiplin Kerja (X), sedangkan variabel dependen (variabel terikat) adalah Motivasi Kerja. Berdasarkan kerangka pemikiran diatas, maka hipotesis yang digunakan dalam penelitian ini adalah sebagai berikut :"Diduga disiplin kerja (X) berpengaruh signifikan terhadap motivasi (Y) pada Badan Pengembangan Sumber Daya Manusia Provinsi Jambi.

\section{HASIL}

\section{Analisis Deskriptif Variabel Disiplin Kerja $(X)$}

Hasil analisis deskriptif data variabel disiplin kerja yang ada pada Badan Pengembangan Sumber Daya (BPSDM) Provinsi Jambi sebagai salah satu variabel yang diukur melalui analisis deskriptif dengan menggunakan skala likert yang dilihat dari tingkat rata-rata dan tingkat capaian responden. Dimana, disiplin kerja disini dapat digambarkan melalui tujuan dan kemampuan, kepemimpinan, balas jasa, keadilan, waskat, ketegasan, serta sanksi. 
Adapun untuk melihat secara jelas hasil perolehan analisis deskriptif dari variabel disiplin kerja ini sendiri, dapat dilihat pada tabel sebagai berikut :

Tabel 1

Analisis Deskriptif Variabel Disiplin Kerja (X)

\begin{tabular}{|c|c|c|c|c|c|c|c|c|c|c|c|c|c|c|c|}
\hline \multirow{2}{*}{ No } & \multirow{2}{*}{ Indikator } & \multirow{2}{*}{ NK } & \multicolumn{2}{|c|}{ SS } & \multicolumn{2}{|c|}{$S$} & \multicolumn{2}{|r|}{$\mathrm{N}$} & \multicolumn{2}{|c|}{ TS } & \multicolumn{2}{|c|}{ STS } & \multirow{2}{*}{$\mathrm{n}$} & \multirow{2}{*}{$\begin{array}{l}\text { Skor } \\
\text { Total }\end{array}$} & \multirow{2}{*}{ Rerata } \\
\hline & & & $\mathbf{F i}$ & $\%$ & $\mathbf{F i}$ & $\%$ & $\mathbf{F i}$ & $\%$ & Fi & $\%$ & $\mathbf{F i}$ & $\%$ & & & \\
\hline \multirow[t]{2}{*}{1} & Tujuan dan & 11 & 32 & 42,67 & 23 & 30,67 & 16 & 21,33 & 4 & 5,33 & 0 & 0,00 & 75 & 308,00 & Tinggi \\
\hline & Kemampuan & 12 & 37 & 49,33 & 23 & 30,67 & 12 & 16,00 & 2 & 2,67 & 1 & 1,33 & 75 & 318,00 & Tinggi \\
\hline \multirow[t]{2}{*}{2} & Kepemimpinan & 13 & 28 & 37,33 & 29 & 38,67 & 13 & 17,33 & 4 & 5,33 & 1 & 1,33 & 75 & 304,00 & Tinggi \\
\hline & & 14 & 37 & 49,33 & 33 & 44,00 & 4 & 5,33 & 1 & 1,33 & 0 & 0,00 & 75 & 331,00 & Sangat Tinggi \\
\hline \multirow[t]{2}{*}{3} & Balas Jasa & 15 & 39 & 52,00 & 31 & 41,33 & 4 & 5,33 & 1 & 1,33 & 0 & 0,00 & 75 & 333,00 & Sangat Tinggi \\
\hline & & 16 & 43 & 57,33 & 29 & 38,67 & 2 & 2,67 & 1 & 1,33 & 0 & 0,00 & 75 & 339,00 & Sangat Tinggi \\
\hline \multirow[t]{2}{*}{4} & Keadilan & 17 & 23 & 35,38 & 48 & 73,85 & 3 & 4,62 & 1 & 1,54 & 0 & 0,00 & 65 & 318,00 & Tinggi \\
\hline & & 18 & 26 & 34,67 & 31 & 41,33 & 13 & 17,33 & 5 & 6,67 & 0 & 0,00 & 75 & 303,00 & Tinggi \\
\hline \multirow[t]{2}{*}{5} & Waskat & 19 & 26 & 34,67 & 40 & 53,33 & 8 & 10,67 & 1 & 1,33 & 0 & 0,00 & 75 & 316,00 & Tinggi \\
\hline & & 20 & 27 & 36,00 & 39 & 52,00 & 9 & 12,00 & 0 & 0,00 & 0 & 0,00 & 75 & 318,00 & Tinggi \\
\hline \multirow[t]{2}{*}{6} & Ketegasan & 21 & 39 & 60,00 & 30 & 46,15 & 6 & 9,23 & 0 & 0,00 & 0 & 0,00 & 65 & 333,00 & Sangat Tinggi \\
\hline & & 22 & 18 & 24,00 & 27 & 36,00 & 16 & 21,33 & 14 & 18,67 & 0 & 0,00 & 75 & 274,00 & Tinggi \\
\hline \multirow[t]{3}{*}{7} & Sanksi & 23 & 36 & 48,00 & 31 & 41,33 & 6 & 8,00 & 2 & 2,67 & 0 & 0,00 & 75 & 326,00 & Sangat Tinggi \\
\hline & & 24 & 47 & 62,67 & 24 & 32,00 & 3 & 4,00 & 1 & 1,33 & 0 & 0,00 & 75 & 342,00 & Sangt Tinggi \\
\hline & Jumlah & & & & & & & & & & & & & 3.188 & Cukup Baik \\
\hline
\end{tabular}

Sumber : Data Diolah.

Berdasarkan tabel di atas, dapat dikatakan bahwa disiplin kerja yang dimiliki para pegawai pada Badan Pengembangan Sumber Daya (BPSDM) Provinsi Jambi termasuk ke dalam kategori “cukup Baik" dengan rata-rata variabel disiplin kerja (X2) sebesar 3.188 dengan rentang skala 2.730 - 3.569. Dengan demikian, adanya tujuan dan kemampuan, kepemimpinan, balas jasa, keadilan, waskat, ketegasan, serta sanksi, pada akhirnya akan dapat meningkatkan kinerja pegawai pada Badan Pengembangan Sumber Daya Manusia Provinsi Jambi.

\section{Analisis Deskriptif Variabel Motivasi (Y)}

Hasil analisis deskriptif data variabel motivasi para pegawai yang ada pada Badan Pengembangan Sumber Daya (BPSDM) Provinsi Jambi sebagai salah satu variabel yang diukur melalui analisis deskriptif dengan menggunakan skala likert yang dilihat dari tingkat rata-rata dan tingkat capaian responden. Dimana, motivasi para pegawai disini dapat digambarkan melalui prestasi kerja yang tinggi, gaji yang tinggi, mempunyai dedikasi yang tinggi, menyenangi profesinya, bekerja karena panggilan hati nurani, dan mendapatkan penghargaan dari pimpinan. Adapun untuk melihat secara jelas hasil perolehan analisis deskriptif dari variabel motivasi ini sendiri, dapat dilihat pada tabel sebagai berikut

Tabel 2

Analisis Deskriptif Variabel Motivasi (Y)

\begin{tabular}{|c|c|c|c|c|c|c|c|c|c|c|c|c|c|c|c|}
\hline \multirow{2}{*}{ No } & \multirow{2}{*}{ Indikator } & \multirow{2}{*}{ NK } & \multicolumn{2}{|l|}{ SS } & \multicolumn{2}{|l|}{$\mathbf{S}$} & \multicolumn{2}{|l|}{$\mathbf{N}$} & \multicolumn{2}{|l|}{ TS } & \multicolumn{2}{|c|}{ STS } & \multirow[b]{2}{*}{$\mathbf{n}$} & \multirow{2}{*}{$\begin{array}{l}\text { Skor } \\
\text { Total }\end{array}$} & \multirow{2}{*}{ Rerata } \\
\hline & & & $\mathbf{F i}$ & $\%$ & $\mathbf{F i}$ & $\%$ & $\mathbf{F i}$ & $\%$ & $\mathbf{F i}$ & $\%$ & $\mathbf{F i}$ & $\%$ & & & \\
\hline \multirow[t]{2}{*}{1} & Prestasi Kerja & 25 & 41 & 54,67 & 27 & 36,00 & 5 & 6,67 & 2 & 2,67 & 0 & 0,00 & 75 & 332 & Sangat Tinggi \\
\hline & Yang Tinggi & 26 & 24 & 32,00 & 44 & 58,67 & 6 & 8,00 & 1 & 1,33 & 0 & 0,00 & 75 & 316 & Tinggi \\
\hline \multirow[t]{2}{*}{2} & Gaji Yang Tinggi & 27 & 22 & 29,33 & 25 & 33,33 & 16 & 21,33 & 10 & 13,33 & 2 & 2,67 & 75 & 280 & Tinggi \\
\hline & & 28 & 46 & 61,33 & 23 & 30,67 & 5 & 6,67 & 1 & 1,33 & 0 & 0,00 & 75 & 339 & Sangat Tinggi \\
\hline \multirow[t]{2}{*}{3} & Tanggung Jawab & 29 & 41 & 54,67 & 27 & 36,00 & 6 & 8,00 & 1 & 1,33 & 0 & 0,00 & 75 & 333 & Sangat Tinggi \\
\hline & Yang Tinggi & 30 & 26 & 34,67 & 32 & 42,67 & 12 & 16,00 & 5 & 6,67 & 0 & 0,00 & 75 & 304 & Tinggi \\
\hline \multirow[t]{2}{*}{4} & Dedikasi Yang & 31 & 23 & 30,67 & 26 & 34,67 & 14 & 18,67 & 8 & 10,67 & 4 & 5,33 & 75 & 281 & Tinggi \\
\hline & Tinggi & 32 & 24 & 32,00 & 40 & 53,33 & 11 & 14,67 & 0 & 0,00 & 0 & 0,00 & 75 & 313 & Tinggi \\
\hline \multirow[t]{2}{*}{5} & Menyenangi & 33 & 21 & 28,00 & 47 & 62,67 & 5 & 6,67 & 2 & 2,67 & 0 & 0,00 & 75 & 312 & Tinggi \\
\hline & Profesinya & 34 & 12 & 16,00 & 43 & 57,33 & 12 & 16,00 & 7 & 9,33 & 1 & 1,33 & 75 & 283 & Tinggi \\
\hline \multirow[t]{2}{*}{6} & Penghargaan & 35 & 23 & 30,67 & 40 & 53,33 & 8 & 10,67 & 4 & 5,33 & 0 & 0,00 & 75 & 307 & Tinggi \\
\hline & $\begin{array}{l}\text { Dari Pimpinan } \\
\text { Jumlah........... }\end{array}$ & 36 & 41 & 54,67 & 28 & 37,33 & 6 & 8,00 & 0 & 0,00 & 0 & 0,00 & 75 & $\begin{array}{l}335 \\
\mathbf{3 . 1 1 3}\end{array}$ & $\begin{array}{l}\text { Sangat Tinggi } \\
\text { Baik }\end{array}$ \\
\hline
\end{tabular}

Sumber : Data Diolah.

Berdasarkan tabel di atas, dapat dikatakan bahwa motivasi pegawai dalam bekerja pada Badan Pengembangan Sumber Daya (BPSDM) Provinsi Jambi termasuk ke dalam kategori "baik" dengan rata-rata variabel motivasi (Y) sebesar 3.113 serta rentang skala 3.060 - 3.779. Dengan demikian, dengan adanya prestasi kerja yang tinggi, gaji yang 
tinggi, mempunyai tanggung jawab yang tinggi, mempunyai dedikasi yang tinggi, menyenangi profesinya, dan mendapatkan penghargaan dari pimpinan, pada akhirnya akan mampu untuk meningkatkan kinerja pegawai pada Badan Pengembangan Sumber Daya (BPSDM) Provinsi Jambi.

Tabel 3

Variabel Disiplin Kerja (X) Terhadap Motivasi (Y)

\begin{tabular}{|l|l|r|c|c|c|c|}
\hline \multirow{2}{*}{ Model } & \multicolumn{2}{|l|}{ Unstandardized Coefficients } & Standardized Coefficients & & \multirow{2}{*}{ Sig. } \\
\cline { 2 - 7 } & \multicolumn{2}{|c|}{ B } & Std. Error & Beta & 2.591 & .012 \\
\hline 1 & (Constant) & .481 & .186 & .257 & 2.257 & .027 \\
\hline
\end{tabular}

Sumber : Data Diolah.

Berdasarkan tabel di atas, maka dapat diketahui perolehan hasil analisis koefisien jalur pada variabel Disiplin Kerja (X) terhadap Motivasi (Y) yang dapat dilihat pada gambar sebagai berikut :

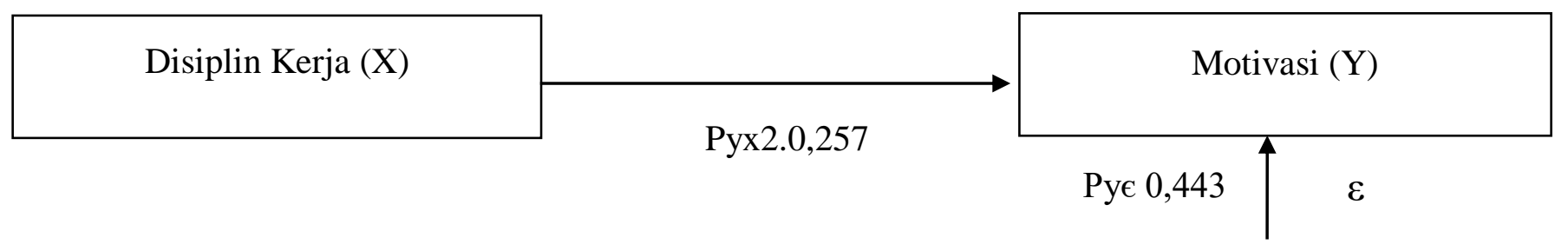

\section{Pengaruh Disiplin Kerja (X) Terhadap Motivasi (Y) pegawai Badan Pengembangan Sumber Daya (BPSDM) Provinsi Jambi}

$\mathrm{X} \rightarrow \mathrm{Y}$, dimana $\mathrm{Y}=\rho \mathrm{\rho x}$. Pyx

$=0,257 \times 0,257$

$=0,066049$

$=6,60 \%$

Perhitungan diatas, dapat dijelaskan bahwasanya terdapat pengaruh langsung antara variabel Disiplin kerja (X2) terhadap motivasi (Y) sebesar 6,60\%. hal ini menunjukan disiplin kerja berpengaruh terhadap motivasi. Setiap terjadi peningkatan disiplin pegawai dalam melakukan pekerjaan maka akan memberikan dampak terhadap peningkatan motivasi kerja adalah sebesar 6,60\%. Hasil penelitian ini memberikan gambaran bahwa untuk meningkatkan motivasi kerja dapat dilakukan dengan meningkatkan disiplin kerja pegawai.

\section{Analisa dan Pembahasan}

Pembahasan berikut ini untuk menguji Disiplin Kerja (X) dan motivasi (Y) Badan Pengembangan Sumber Daya (BPSDM) Provinsi Jambi. Data hasil penelitian dengan karakteristik Disiplin Kerja (X), dan motivasi (Y) sebagai berikut:

Tabel 4

Hasil Analisis Deskriptif Per Variabel

\begin{tabular}{lllll}
\hline No & Variabel & Total Skor & Rentang Skala & Hasil Hipotesis \\
\hline 1 & Disiplin Kerja & 3.188 & $2.730-3.569$ & Cukup Baik \\
2 & Motivasi & 3.113 & $3.060-3.779$ & Baik \\
\hline
\end{tabular}

Sumber : Data Diolah.

Data diatas, dapat digambarkan bahwasanya disiplin kerja (X) mendapatkan total skor 3.188 yang berarti cukup baik, sedangkan motivasi (Y) mendapatkan total skor sebesar 3.113 yang berarti baik. Dengan demikian, dilihat dari adanya kualitas kerja, ketepatan waktu, inisiatif, kesanggupan kerja, dan keterampilan berkomunikasi, dapat meningkatkan motivasi pegawai untuk selalu menyumbangkan prestasi kerja mereka, dan pada akhirnya akan meningkatkan kepercayaan para masyarakat terhadap eksistensi dan kinerja yang bertanggung jawab, sesuai dengan tujuan yang diinginkan.

Hasil iini menunjukkan adanya pengaruh Disiplin Kerja (X) terhadap Motivasi (Y) pada Badan Pengembangan Sumber Daya (BPSDM) Provinsi Jambi. Hasil perhitungan dengan menggunakan software SPSS 19 seperti yang ditunjukkan pada tabel di atas, disiplin kerja $(\mathrm{X})$ dengan variabel motivasi (Y) menunjukkan bahwa t hitung 2,257 dengan Sig. 0,027. Kriteria keputusan jika Sig. penelitian $<0,05$ maka H0 di tolak dan H1 diterima artinya signifikan, tetapi jika Sig. penelitian > 0,05 maka H0 diterima dan $\mathrm{H} 1$ di tolak yang berarti tidak signifikan. Karena 0,027 $<0,05$ maka H0 di terima dan $\mathrm{H} 1$ ditolak. Hasil ini menunjukkan bahwa disiplin kerja (X) pegawai pada Badan 
Pengembangan Sumber Daya (BPSDM) Provinsi Jambi pengaruh secara positif dan signifikan terhadap motivasi (Y) dan hipotesis di terima. Hasil ini memperkuat penelitian Sulastri (2007:20), dimana berdasarkan hasil pengujian, diketahui bahwa semakin tinggi disiplin maka semakin tinggi pula motivasi dalam bekerja yang ditunjukkan oleh para dosen di UNISMA Bekasi.

\section{SIMPULAN}

Dari hasil penelitian dan pembahasan penelitian sebagaimana yang telah diuraikan dapat disimpulkan bahwa disiplin kerja yang ada pada Badan Pengembangan Sumber Daya (BPSDM) Provinsi Jambi secara rata-rata termasuk ke dalam kategori cukup baik. Dan motivasi pegawai dalam bekerja pada Badan Pengembangan Sumber Daya (BPSDM) Provinsi Jambi secara rata-rata termasuk ke dalam kategori baik.

Disiplin kerja berpengaruh positif dan signifikan terhadap motivasi pegawai pada Badan Pengembangan Sumber Daya (BPSDM) Provinsi Jambi. Ini memberikan arti bahwa dengan adanya disiplin dalam bekerja tentu membuat pegawai akan lebih bertanggung jawab pada pekerjaan yang diberikan kepada mereka.

\section{DAFTAR PUSTAKA}

Aroef, M. 2006. "Pengukuran Kinerja Kebutuhan Mendasar di Indonesia". Prisma No.11. LP3ES. Jakarta.

Dessler, G. 1999. "Human Resources Management”. Penerjemah Benyamin Molan. Jakarta : PT. Prehalindo.

Fathoni, A. 2006. "Organisasi dan Manajemen Sumber Daya Manusia". Jakarta : PT. Rineka Cipta.

Fikri, M. 2012. (Tesis). "Pengaruh Kepemimpinan dan Motivasi Kerja Terhadap Kinerja Pegawai Pada Dinas Pendapatan Daerah Provinsi Jambi". Magister Manajemen, FE, Universitas Batanghari Kota Jambi, (tidak dipublikasikan).

Gomes, L. 1998. "Managing Human Resources". New Jersey : Prentice Hall International, Inc.

Handoko, T.H. 2002. "Manajemen Sumber Daya Manusia". Yogyakarta : BPFE UGM.

Hariandja, M.T Effendi. 2002. "Manajemen Sumber Daya Manusia". Jakarta : PT. Grasindo.

Harsey, R, Leo J, dan Maynard. 1993. "Human Resources Management”. New Jersey : Prentice Hall International, Inc.

Harsey, R, Paul, Blanchard, Kenneth H, dan Johnson. 2002. "Management of Organizational Behaviour Utilizing Human Resources". New Jersey : Prentice Hall International, Inc.

Hasan, M. Iqbal. 2005. "Pokok-pokok Materi Statistik I (statistik deskriptif); Edisi Kedua". Jakarta : Bumi Aksara.

Hasibuan, Malayu SP. 2000. "Manajemen Sumber Daya Manusia dan Kunci Keberhasilan”. Bandung : Armanco. 2002. "Manajemen Sumber Daya Manusia". Jakarta : Bumi Aksara.

Lubis, F. 2011. (Tesis). "Pengaruh Motivasi dan Disiplin Kerja Terhadap Kinerja Pegawai Dinas Pendapatan Daerah Provinsi Jambi”. Magister Manajemen, FE, Universitas Batanghari Kota Jambi, (tidak dipublikasikan).

Mangkunegara, A.A. Anwar Prabu. 2000. "Manajemen Sumber Daya Manusia". Bandung : PT. Remaja Rosda Karya. . 2005. "Evaluasi Kinerja SDM". Bandung : PT. Refika Aditama.

Muhidin, S.A \& Maman. 2007. "Analisis Korelasi, Regresi, dan Jalur Dalam Penelitian”. Bandung : Pustaka Setia.

Ndraha, T. 1999. "Pengembangan Sumber Daya Manusia". Jakarta : PT. Rineka Cipta.

Pangabean, M. 2002. "Pengembangan Sumber Daya Manusia”. Jakarta : PT. Rineka Cipta.

Ranupandojo, Heidjrahcman, dan Suad H. 2000. "Manajemen Personalia". Yogyakarta : BPFE UGM.

Riduwan \& Akdon. 2009. "Rumus dan Data dalam Analisis Statistika". Bandung : Alfabeta.

Robbins, S.P. 2001. "Perilaku Organisasi”. Jakarta : Arcan.

Rubianto, B. 2001. "Kepemimpinan Perusahaan Dalam Industri”. Jakarta : YKPN.

Sastrohadiwiryo, Siswanto. 2002. "Manajemen Tenaga Kerja Indonesia : Pendekatan Administratif dan Operasional". Jakarta : Bumi Aksara.

Schermerhorn, J. 2005. "Manajemen Strategi". Penerjemah JS Molan. Jakarta : YKPN.

Schuler, J dan Jackson. 1996. "Manajemen Sumber Daya Manusia, Jilid II". Jakarta : PT. Erlangga.

Sedarmayanti. 2002. "Manajemen Sumber Daya Manusia". Bandung : Mandar Maju.

Selviati, V. 2013. "Pengaruh Gaya Kepemimpinan, Motivasi, Disiplin Kerja, dan Kompensasi Terhadap Kinerja Pegawai Bidang Pendapatan, Bidang Anggaran dan Perbendaharaan DPPKAD Kota Tanjungpinang”. Jurnal Ilmiah. Hal : 1-15.

Siagian, S. P. 1999. "Teori Motivasi dan Aplikasinya”. Jakarta : PT. Rineka Cipta.

2005. "Manajemen Sumber Daya Manusia". Bandung : Bumi Aksara.

2007. "Kiat Meningkatkan Produktivitas Kerja". Jakarta : PT. Rineka Cipta.

Sugiyono. 2005. "Statistik Untuk Penelitian". Bandung : CV. Alfabeta.

.2012. "Metode Penelitian Kuantitatif, Kualitatif Dan Kombinasi (Mixed Methods)". Bandung : CV.

Alfabeta. 
Sulastri, T. 2007. "Hubungan Motivasi Berprestasi dan Disiplin Dengan Kinerja Dosen". Jurnal Optimal, Vol. 1, No. 1, Maret 2007. Hal : 13-21.

Sulistiyani, A.T dan Rosidah. 2003. "Manajemen Sumber Daya Manusia". Yogyakarta : Graha Ilmu.

Supardi (2013) “Aplikasi Statistika Dalam Penelitian, Konsep Statistika Yang Lebih Komprehensif”. cetakan 1 Juni 2013, Change Pulication, Jakarta.

Suparman. 2007. (Tesis). "Pengaruh Kepemimpinan dan Motivasi Kerja Terhadap Kinerja Karyawan”. Magister Manajemen, FE, Universitas Batanghari Kota Jambi, (tidak dipublikasikan).

Umar, Husein. 2007. "Desain Penelitian MSDM dan Perilaku Karyawan : Paradigma Positivistik dan Berbasis Pemecahan Masalah". Jakarta : PT. Raja Grafindo Persada.

Yuda. 2012. Jurnal Tesis. "Kontribusi Perilaku Kepemimpinan Kepala Sekolah, Motivasi Kerja, dan Disiplin Kerja Terhadap Kinerja Guru Rintisan Sekolah Menengah Atas Bertaraf Internasional (RSMABI) di Kota Denpasar”. Universitas Pendidikan Ganesha.

M. Oktaviannur, Adhetya Pratama, Influence Of Work Motivation And Work Discipline On The Performance Of Employees In Regional General Hospital In The District Demang Sepulau Raya Central Lampung, International Conference On Law, Business And Governance (Icon-Lbg) Bandar Lampung University. 2016.

Eva Lestari Bangun, Dr. Kasmir SE. Discipline Effect, Motivation and Work Environment to Employee Performance in PT. Telecommunication of Indonesia TBK, Witel Bogor. International Journal of Innovative Science and Research Technology Volume 4, Issue 11, November - 2019. 